Reconnaissance Assessment of Erosion and Sedimentation in the Cañada de los Alamos Basin, Los Angeles and Ventura Counties, California

GEOLOGICAL SURVEY WATER-SUPPLY PAPER 2061

Prepared in cooperation with the California Department of Water Resources

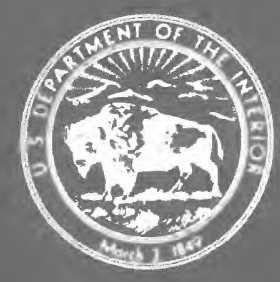




\title{
Reconnaissance Assessment of
} Erosion and Sedimentation in the Cañada de los Alamos Basin, Los Angeles and Ventura Counties, California

\author{
By J. M. KNOTT
}

GEOLOGICAL SURVEY WATER-SUPPLY PAPER 2061

Prepared in cooperation with the

California Department of Water Resources

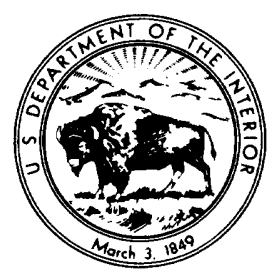




\section{UNITED STATES DEPARTMENT OF THE INTERIOR}

CECIL D. ANDRUS, Secretary

\section{GEOLOGICAL SURVEY}

H. William Menard, Director

Library of Congress Card-Catalog number 80-600012

For sale by the Superintendent of Documents, U. S. Government Printing Office Washington, D. C. 20402

Stock number 024-001-03283-0 


\section{CONTENTS}

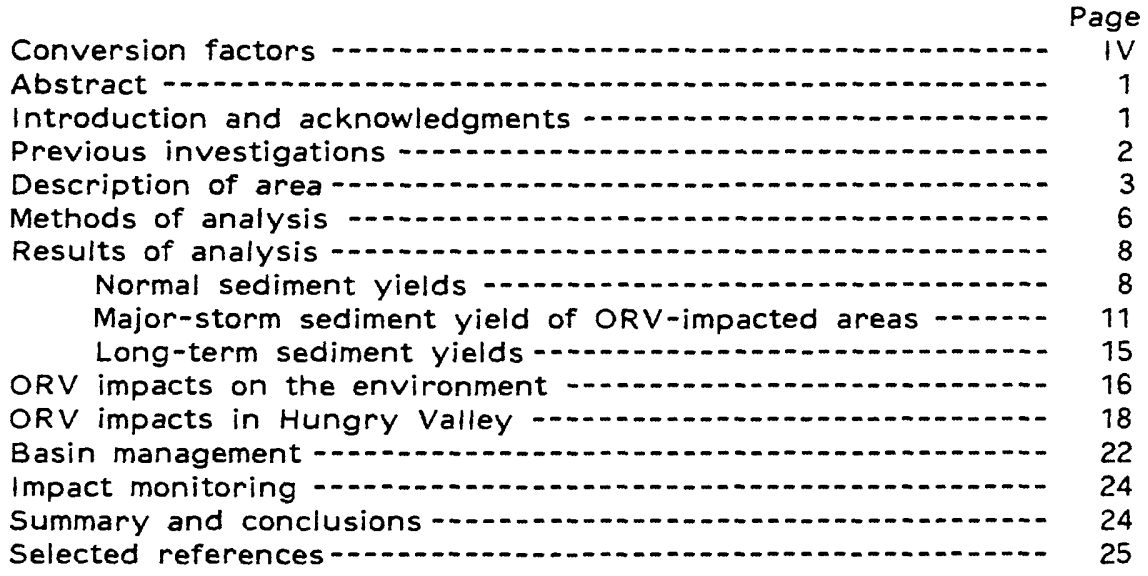

\section{ILLUSTRATIONS}

Figure 1. Map showing location of the Cañada de los

2. Sketch map showing physiographic units......... 5

3. Photograph showing view looking west from "Bench Mark Hill" at areas of ORV use in upper Hungry Valley ............................... 7

4. Sketch map showing distribution of private and Federal lands in the upper Hungry Valley

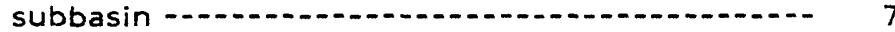

5-12. Photographs showing--

5. ORV trails on a moderate size hill, January 1976 -... 12

6. Same hill in January $1978 \ldots 12$

7. Same hill in April 1978

8. "Bench Mark Hill" in January $1976 \ldots$

9. "Bench Mark Hill" in January $1978 \ldots 19$

10. "Bench Mark Hill" in March 1978 .......... 20

11. Severely eroded benchmark in January 1976 -. 20

12. One of numerous gullies formed at the base of "Bench Mark Hill" during the February and March 1978 rainstorms 
Figures 13-15. Photographs showing--

13. Trenches eroded by surface abrasion of

ORV's on top of "Bench Mark Hill" ...

14. Lateral migration of Cañada de los Alamos near Kinsey Ranch during February and March 1978 .................... 22

15. Downcutting of a tributary to Cañada de los Alamos near Kinsey Ranch -........

\section{TABLES}

Table 1. Normal major-storm sediment yields and related parameters for the Cañada de los Alamos basin

2. Dimensions and volume of a gully network in

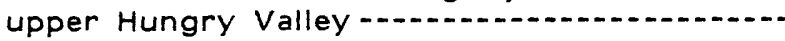

\section{CONVERSION FACTORS}

For readers who may prefer to use metric units (International System of Units), conversion factors for the terms used in this report are listed below.

\begin{tabular}{|c|c|c|}
\hline$\frac{\text { Multiply inch-pound }}{\text { unit }}$ & By & $\frac{\text { To obtain metric }}{\text { (SI) unit }}$ \\
\hline $\begin{array}{l}\text { acre } \\
\text { acre } / \mathrm{mi}^{2} \text { (acre per } \\
\quad \text { square mile) }\end{array}$ & $\begin{array}{l}0.4047 \\
0.1563\end{array}$ & $\begin{array}{l}\mathrm{hm}^{2} \text { (square hectometer) } \\
\mathrm{hm}^{2} / \mathrm{km}^{2} \text { (square hecto- } \\
\text { meter per square kilo- } \\
\text { meter) }\end{array}$ \\
\hline $\begin{array}{l}\mathrm{ft} \text { (foot) } \\
\text { in. (inch) } \\
\mathrm{Ib} / \mathrm{ft}^{2} \text { (pound per } \\
\text { square foot) }\end{array}$ & $\begin{array}{l}0.3048 \\
25.4 \\
4.881\end{array}$ & $\begin{array}{l}\mathrm{m} \text { (meter) } \\
\mathrm{mm} \text { (millimeter) } \\
\mathrm{kg} / \mathrm{m}^{2} \text { (kilogram per } \\
\text { square meter) }\end{array}$ \\
\hline $\begin{array}{l}\mathrm{Ib} / \mathrm{ft}^{3} \text { (pound per } \\
\text { cubic foot) }\end{array}$ & 16.02 & $\begin{array}{l}\mathrm{kg} / \mathrm{m}^{3} \text { (kilogram per } \\
\text { cubic meter) }\end{array}$ \\
\hline $\begin{array}{l}\mathrm{mi} \text { (mile) } \\
\mathrm{mi}^{2} \text { (square mile) } \\
\mathrm{yd}^{3} \text { (cubic yard) } \\
\mathrm{yd}^{3} / \mathrm{mi}^{2} \text { (cubic yard } \\
\text { per square mile) }\end{array}$ & $\begin{array}{l}1.609 \\
2.590 \\
0.7646 \\
0.2952\end{array}$ & $\begin{array}{l}\mathrm{km} \text { (kilometer) } \\
\mathrm{km}^{2} \text { (square kilometer) } \\
\mathrm{m}^{3} \text { (cubic meter) } \\
\mathrm{m}^{3} / \mathrm{km}^{2} \text { (cubic meter } \\
\text { per square kilometer) }\end{array}$ \\
\hline
\end{tabular}




\section{RECONNAISSANCE ASSESSMENT OF EROSION AND SEDIMENTATION IN THE CAÑADA DE LOS ALAMOS BASIN, LOS ANGELES AND VENTURA COUNTIES, CALIFORNIA}

\section{By J. M. Knott}

\section{ABSTRACT}

An assessment of present erosion and sedimentation conditions in the Cañada de los Alamos basin was made to aid in estimating the impact of off-road-vehicle use on the sediment yield of the basin. Impacts of off-road vehicles were evaluated by reconnaissance techniques and by comparing the study area with other offroad-vehicle sites in California.

Major-storm sediment yields for the basin were estimated, using empirical equations developed for the Transverse Ranges and measurements of gully erosion in a representative off-road-vehicle basin. Normal major-storm yields of 73,200 cubic yards would have to be increased to about 98,000 cubic yards to account for the existing level of accelerated erosion caused by off-road vehicles.

Long-term sediment yield of the Cañada de los Alamos basin upstream from its confluence with Gorman Creek, under present conditions of off-road-vehicle use, is approximately 420 cubic yards per square mile per year--a rate that is considerably lower than a previous estimate of 1,270 cubic yards per square mile per year for the total catchment area above Pyramid Lake.

\section{INTRODUCTION AND ACKNOWLEDGMENTS}

Current planning of the California Department of Water Resources is concerned with the development of recreation sites in Hungry Valley near Gorman, Calif. One of these developments includes a proposal 
of the California Department of Parks and Recreation for ORV (off-road vehicle) recreation use on a major scale.

The U.S. Geological Survey made a reconnaissance study of erosion and sedimentation in the Hungry Valley area in cooperation with the California Department of Water Resources. The objectives of this study were to assess present erosion and sediment conditions in the Cañada de los Alamos basin upstream from its confluence with Gorman Creek (fig. 1), an area that includes Hungry Valley, and to estimate the probable impact of current ORV use on the sediment yield of the basin.

This report includes the observations of the author during two brief visits to the study area, a limited review of literature dealing with ORV-impacted areas in California, estimates of sediment yield, and a discussion of impacts of ORV use and possible basinmanagement measures that could reduce erosion and sediment yield in the basin.

The author is grateful to Richard Angelos, California Department of Water Resources, and to Howard G. Wilshire and Kevin M. Scott, U.S. Geological Survey, for their valuable contributions of background information and technical advice.

\section{PREVIOUS INVESTIGATIONS}

Several investigations related to erosion or sedimentation have been made in the vicinity of the study area. Crowell (1950) mapped the geology of the Hungry Valley area and discussed the evolution of sediments in Hungry and Peace Valleys. Scott, Ritter, and Knott (1968) estimated the probable sediment yield for various parts of the Piru Creek basin from data collected in the basin and from correlation with sediment yields of other basins in the Transverse Ranges. Scott and Williams (1978) estimated the major-storm sediment yields for the Real and Warring Canyon basins from correlation with similar basins having measured sediment yields. Wilshire and Nakata (1978) measured erosion rates and discussed major impacts associated with ORV use in Hungry Valley after January 1976. 


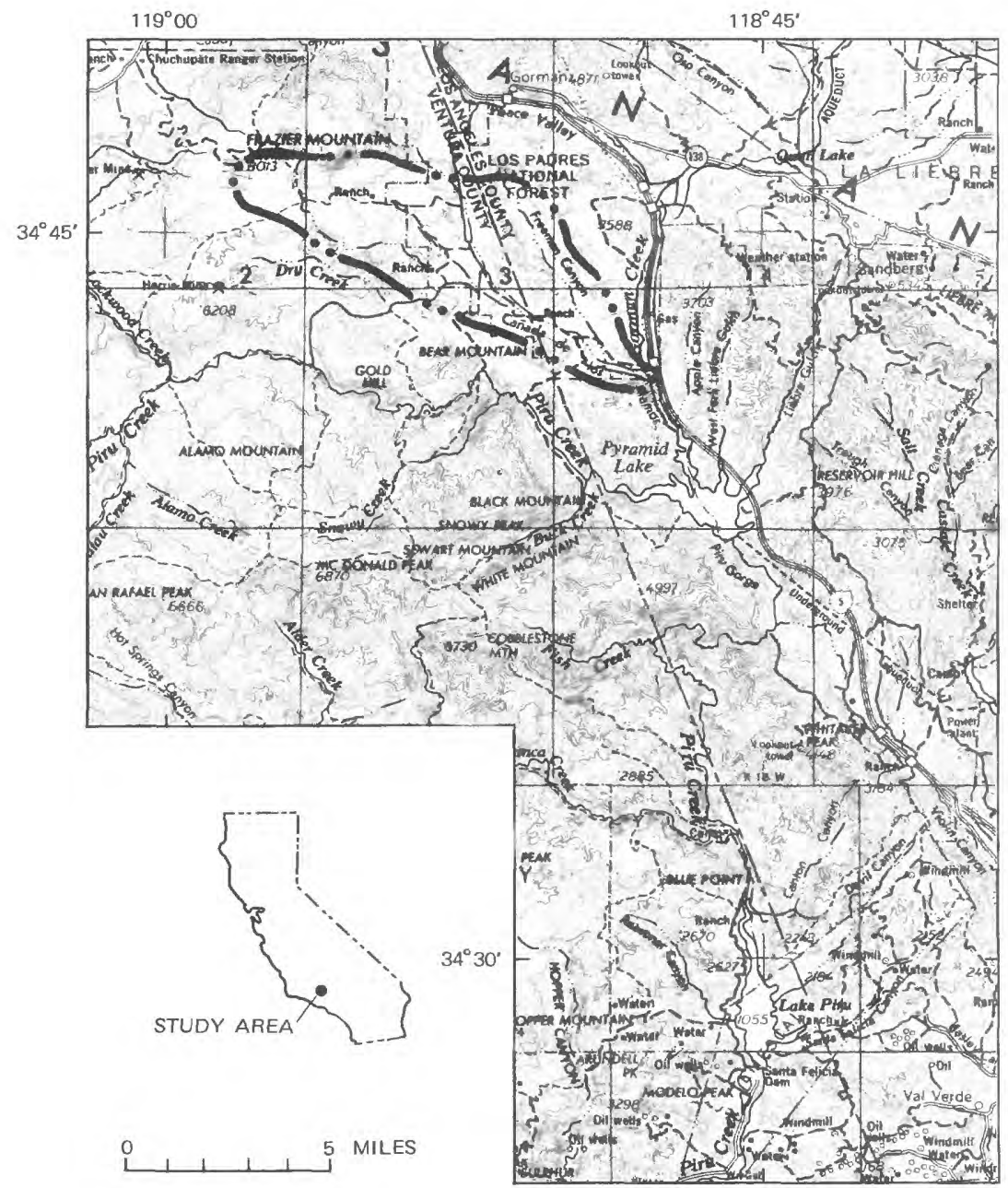

FIGURE 1.--Location of the Cañada de los Alamos basin, Calif.

\section{DESCRIPTION OF AREA}

The Cañada de los Alamos basin (fig. 1), as referred to in this report, includes the entire drainage area $\left(31 \mathrm{mi}^{2}\right)$ upstream from its confluence with 
Gorman Creek. The basin lies along the Los Angeles-Ventura County line near Gorman, Calif., in the Transverse Ranges of southern California.

The study area can be divided into three distinct physiographic units (fig. 2). The western unit is the Maxy Canyon subbasin (drainage area, 7.00 $\mathrm{mi}^{2}$ ). This area is isolated, heavily forested, and rather rugged, with altitudes greater than $8,000 \mathrm{ft}$ at Frazier Mountain (fig. 1). Mean annual precipitation ranges from 15 to 18 inches (Rantz, 1969). The mountains consist of Quaternary nonmarine terrace deposits and late Pliocene nonmarine sedimentary rocks lying on a basement complex of Precambrian metamorphic rocks (Jennings and Strand, 1969).

The central unit includes the upper Cañada de los Alamos, upper Hungry Valley, and lower Hungry Valley subbasins (drainage areas, 4.97, 4.67, and $9.35 \mathrm{mi}^{2}$ ). This unit ranges from broad, flat valley areas to mountainous terrain on the western boundary. Vegetation is mostly chaparral, sagebrush, and grass, with forest species of pine and fir at higher altitudes. Mean annual precipitation ranges from 12 inches in Hungry Valley to about 16 inches in the upper drainage area of Cañada de los Alamos. Most of Hungry Valley and the upper Cañada de los Alamos subbasin consists of highly erodible Quaternary alluvium along stream courses. This alluvium lies on a thick sequence of late Pliocene nonmarine sedimentary rocks, also highly erodible, that forms most of the hill topography. Quaternary terrace deposits and metamorphic rocks are found in the upper Cañada de los Alamos subbasin.

The eastern unit is the Freeman Canyon subbasin (drainage area, $5.16 \mathrm{mi}^{2}$ ). It is characterized by a narrow valley covered by sagebrush and juniper woodland. Rainfall is low in this area, averaging only 11 to $12 \mathrm{in} / \mathrm{yr}$. Freeman Canyon contains extensive deposits of Quaternary alluvium which overlie late Pliocene nonmarine sedimentary rocks. 


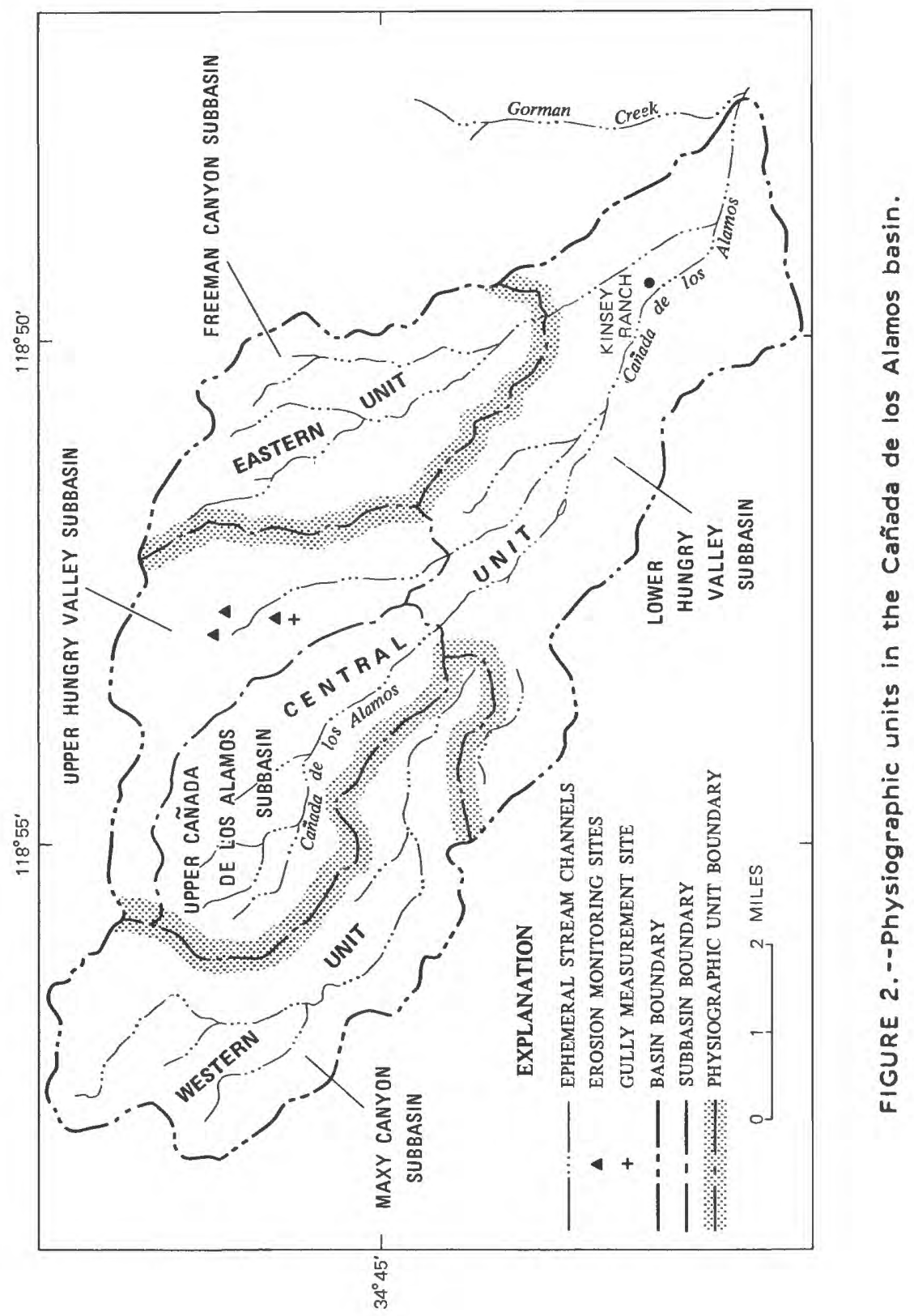


The Cañada de los Alamos basin has few inhabitants. Land use is generally limited to cattle ranching, sheep grazing, minor agriculture, and recreation. The upper part of Hungry Valley has been intensively used for motorcycle hill climbing and other ORV activity (fig. 3) since 1971 (Wilshire, 1977). ORV activity is regulated on lands of the Los Padres National Forest and Bureau of Land Management (fig. 4) but is not regulated on private lands in the upper Hungry Valley subbasin.

\section{METHODS OF ANALYSIS}

The lack of hydrologic data for the study area required that erosion rates and sediment yield be estimated by empirical methods, by observation, and by comparison of physical characteristics of the basin with those of other areas for which data are available.

An empirical method for estimating erosion and sediment yields in mountain basins of the Transverse Ranges (Scott and Williams, 1978) was selected because the study area is within the region used to develop the method and because data for the required parameters are readily available from maps, photographs, or observation. The equation for basins in the Miocene-Pliocene section of the Santa Clara River valley is

$$
\begin{aligned}
\log S y \text { is } 1.244+0.828 \log A+1.382 \log E R+ \\
\\
0.375 \log S F+0.251 \log F F+0.840 \log K
\end{aligned}
$$

where

Sy is total sediment yield during a major storm (50-year recurrence level), in cubic yards

$A$ is drainage area, in square miles;

$E R$ is elongation ratio (the diameter of a circle with an area equal to that of the watershed divided by the maximum watershed length);

SF is area of slope failures, in acres per square mile; 


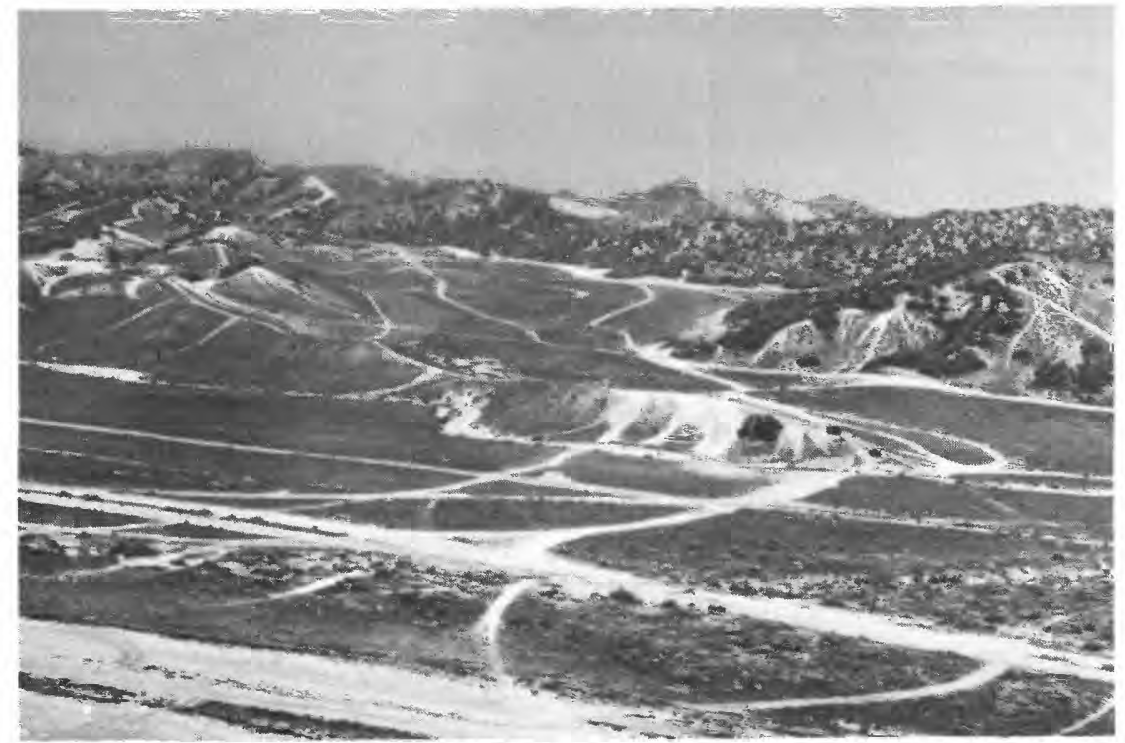

FIGURE 3.--View looking west from "Bench Mark Hill" at areas of ORV use in upper Hungry Valley. Crest of hill in center of photograph is about $70 \mathrm{ft}$ above valley flat.

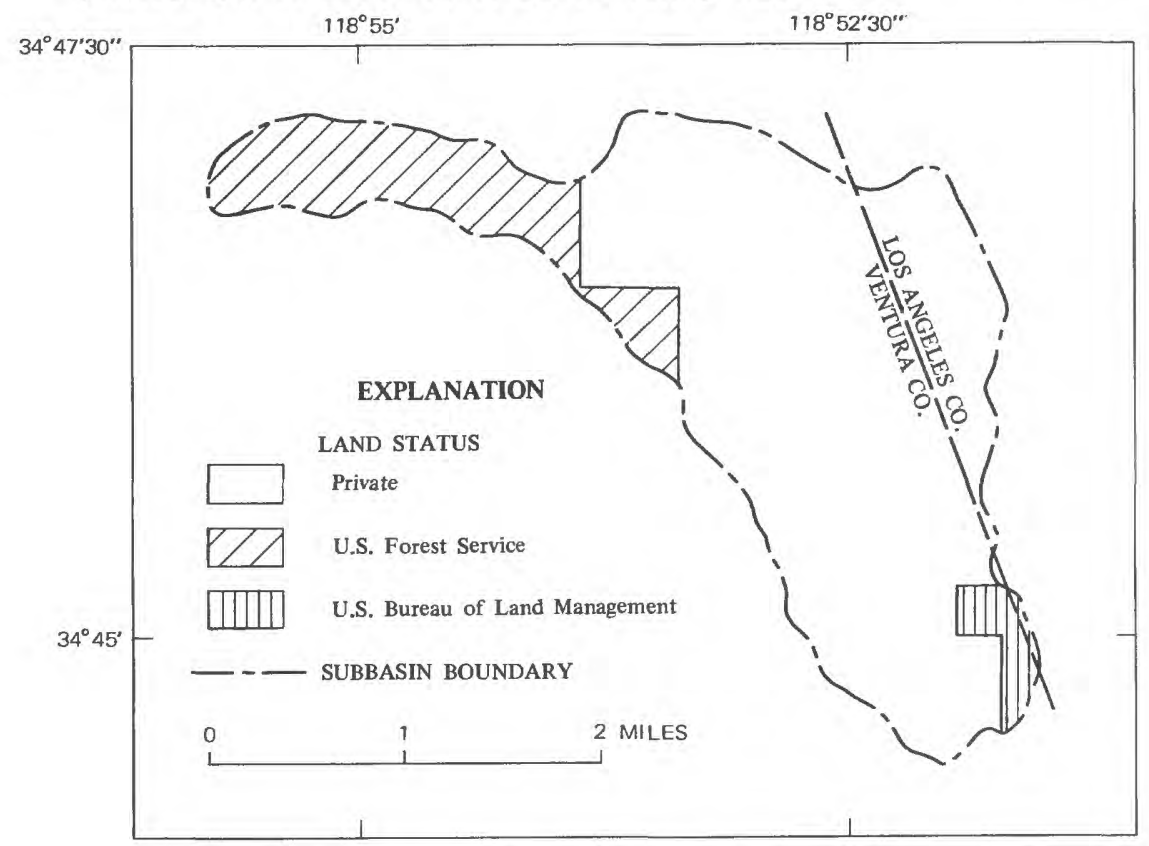

FIGURE 4.--Distribution of private and Federal lands in the upper Hungry Valley subbasin. 
FF is fire factor (the percentage of watershed burned, multiplied by the percentage of nonrecovery of vegetative cover);

$K$ is storm-precipitation factor (the 50-year 10-day total precipitation, multiplied by the square of the 50-year 24-hour precipitation, in inches).

Major-storm sediment yields were computed for four subbasins (fig. 2), designated Maxy Canyon, upper Cañada de los Alamos, upper Hungry Valley, and Freeman Canyon. Major-storm sediment yield was also determined for the entire study area.

Erosion and deposition data obtained by Wilshire (written commun., 1978) for selected sites in the upper Hungry Valley subbasin (fig. 2) were used to evaluate the impact of ORV recreation on the land surface and for comparison with other ORV recreational areas in California. These data consist primarily of sequential photographs, measurements of gully dimensions, and measurements of alluvium loss obtained during the period between January 1976 and April 1978.

The volume of alluvium loss in one gully network was determined during a visit to the upper Hungry Valley subbasin April 19-20, 1978. Gully dimensions were measured and photographs of the gully were compared to those taken by Wilshire in January 1976 and January 1978 to estimate the quantity of alluvium eroded during the intense rainstorms of February and March 1978.

\section{RESULTS OF ANALYSIS}

\section{Normal Sediment Yields}

Erosion and sediment transport in the Transverse Ranges are small or moderate during most years but may be severe during infrequent major storms. The quantity of sediment transported during a 50-year storm is about equal to that transported in 8 to 13 average years in small basins that are not strongly affected by burns (Scott and Williams, 1978). 
The evaluation of erosion and sediment yield during major storms is an important factor to consider in determining the effect of land-use changes on the environment and in the design of measures to reduce or control sediment movement.

Major-storm sediment yields, based on normal climatic and physical characteristics of the Cañada de los Alamos basin, are given in table 1 . The indicated yields reflect the impact of some types of accelerated erosion, such as loss of vegetation by fire or limited grazing, but not of types that disturb the soil structure, such as overgrazing, cultivation, and excavation.

Sediment yields indicated in table 1 for Maxy Canyon, upper Cañada de los Alamos, and Freeman Canyon subbasins are probably representative of normal sediment yields, because the land is relatively unused except for some cattle ranching. Some gullying was observed in and near dirt roads, but accelerated erosion was considered minor.

Sediment yields indicated for the upper Hungry Valley subbasin should be increased substantially to reflect the accelerated erosion caused by ORV activity and poorly maintained roads. During a visit to Hungry Valley in April 1978 the author estimated that about 10 percent of upper Hungry Valley had undergone severe soil disturbance and that an additional 10 percent of the subbasin was moderately affected by partial loss of vegetal cover and extensive gully networks. Most of the major gullies observed in the subbasin were located in ORV areas. The estimates were made from on-site visual observations; more accurate estimates could undoubtedly be made from analysis of aerial photographs.

Sediment yield indicated for the lower Hungry Valley subbasin was computed by subtracting the sediment yields of Maxy Canyon, upper Cañada de los Alamos, upper Hungry Valley, and Freeman Canyon subbasins from that of the total basin. This indicated yield is low compared to the more arid upper Hungry Valley and Freeman Canyon subbasins, probably because of deposition of sediment from the upper subbasins in the flatter reaches of lower Cañada de los Alamos. The indicated yield of lower 


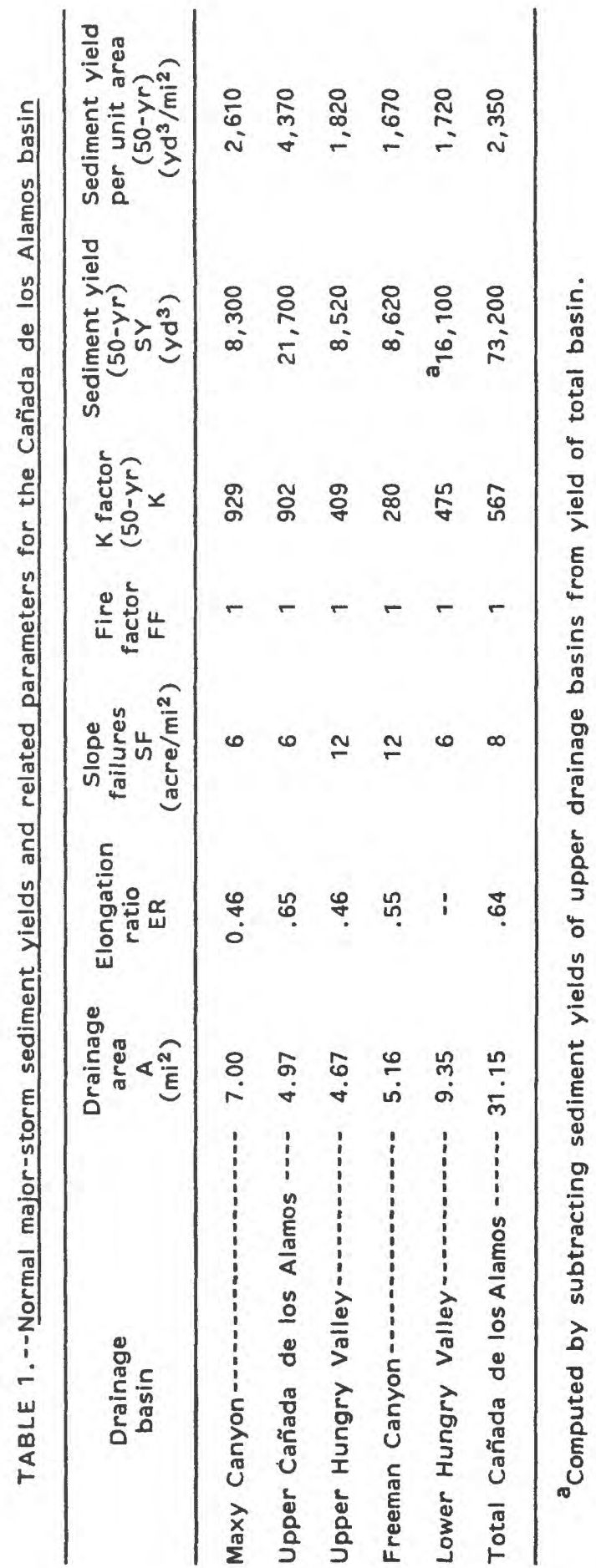


Hungry Valley subbasin should be increased to allow for accelerated erosion caused by ORV use and poorly maintained roads. It was estimated that about 1 percent of this subbasin was impacted by ORV use.

\section{Major-Storm Sediment Yield of ORV-Impacted Areas}

The major-storm sediment yield due to ORV's was approximated by determining the alluvium loss from a small basin $\left(0.02 \mathrm{mi}^{2}\right)$, where ORV use was considered representative of the disturbed and partly disturbed area of upper Hungry Valley, and applying the value of sediment yield per unit area to the impacted area of upper Hungry Valley. Alluvium loss from the basin was determined by measuring the dimensions of a major gully network and visually estimating the average dimensions of upstream rills in and adjacent to ORV trails. Alluvium loss during the major storms of February and March 1978 was estimated on the basis of the enlargement of the gully network as shown in sequential photographs (figs. 5-7).

The gully network selected for measurement is at lat $34^{\circ} 45^{\prime} 39^{\prime \prime} \mathrm{N}$. and long $118^{\circ} 52^{\prime} 47^{\prime \prime} \mathrm{W}$. This gully was small to moderate in size prior to January 1978 (fig. 6); it attained the status of a large gully network during the major storms in February and March 1978 (fig. 7). The gully network is in an area where ORV use has been active, but many other sites were observed in the valley where ORV use was more intensive. Dimensions and volume of the gully network are summarized in table 2 .

If ORV use in the small basin $\left(0.02 \mathrm{mi}^{2}\right)$ shown in figures $5-7$ is assumed to be representative of ORV use in the severely disturbed and moderately disturbed alluvium areas of Hungry Valley, and if the February and March 1978 storms are comparable to a 50-year storm, the major-storm sediment yield caused by ORV use can be approximated. Rainfall-intensity data for the February-March 1978 storms were not available during this study. Rainfall records at the Sandberg PTL climatological station (National Climatic Center, 1969, 1978), however, show close agreement 


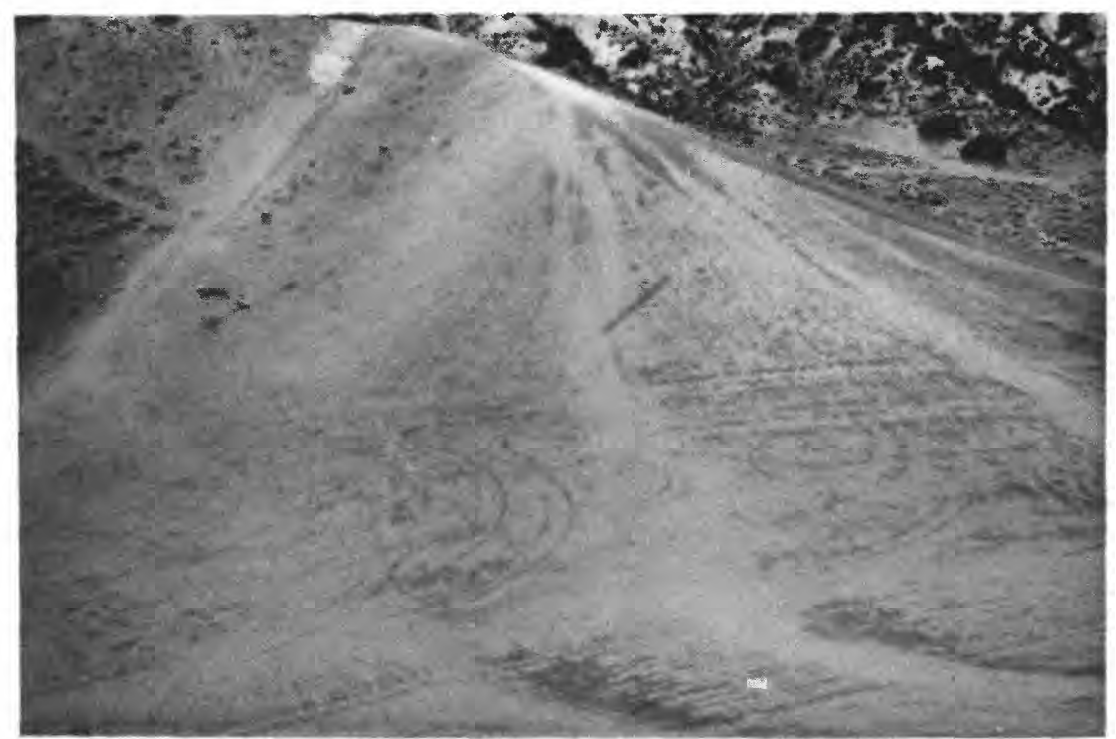

FIGURE 5. - ORV trails on moderate size hill (vertical distance from base to crest about $100 \mathrm{ft}$ ) as seen from crest of "Bench Mark Hill," January 1976. Erosion is largely due to surface abrasion by ORV's. Photograph by Howard Wilshire, Geologic Division, U.S. Geological Survey.

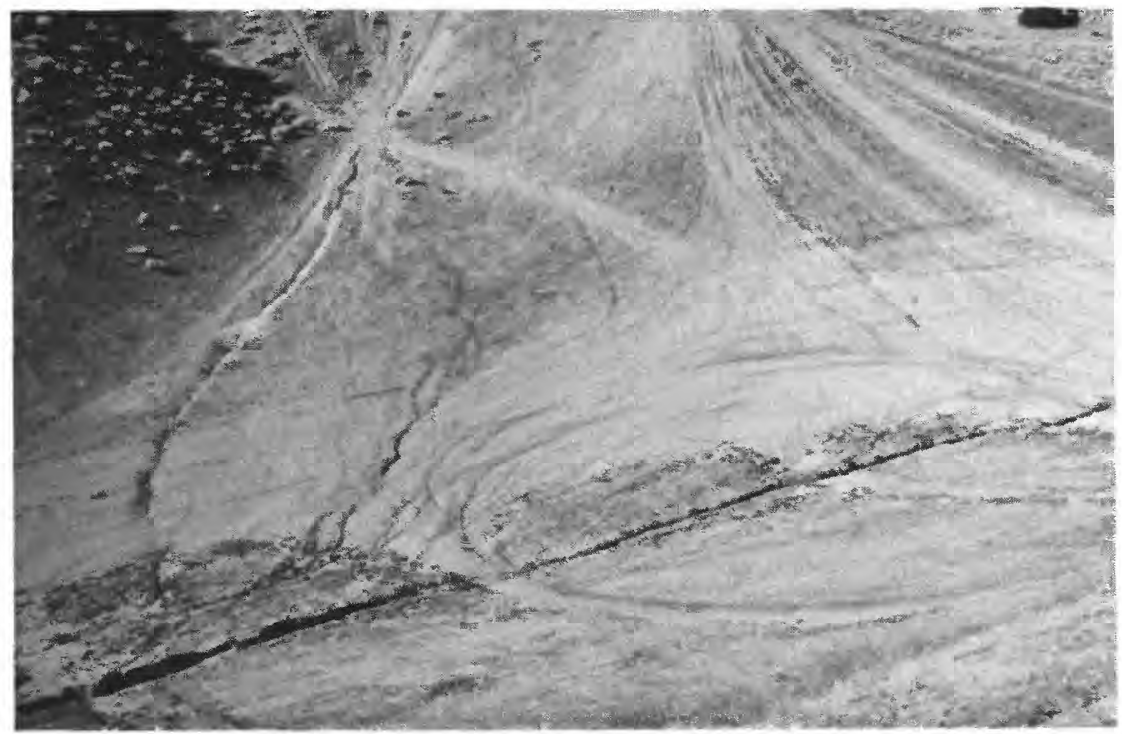

FIGURE 6.--Same hill in January 1978. Rills and small to moderate sized gullies are evident in and adjacent to ORV trails. Main gully in center of photograph is small enough to allow ORV crossing. Photograph by Howard Wilshire, Geologic Division, U.S. Geological Survey. 


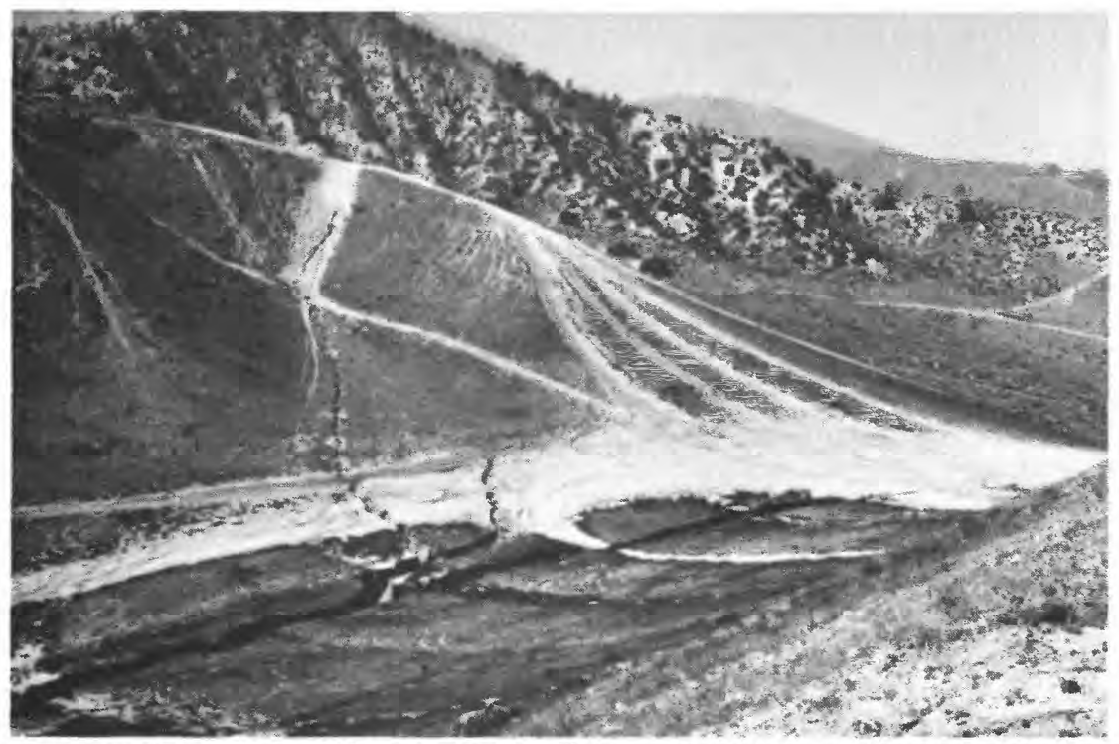

FIGURE 7.--Same hill in April 1978. A major gully network was formed during intense rainstorms in February and March. Main gully at ORV crossing in center of photograph is $5.6 \mathrm{ft}$ wide and $6.5 \mathrm{ft}$ deep.

between daily and total-storm rainfall for the storms of February 28-March 6, 1978, and January 18-27, 1969. Rainfall characteristics for the January 18-27, 1969, storm are generally similar to those of a 50-yr storm in the Transverse Ranges (Scott and Williams, 1978). Computations and other assumptions used to estimate the major-storm sediment yield caused by the present level of ORV use are tabulated below:

1. Examination of sequential photographs (figs. 5-7) suggested that about 80 percent of the alluvium loss in the gully occurred during the February and March 1978 storms.

2. The volume lost is $0.80 \times 1,125 \mathrm{yd}^{3}=900 \mathrm{yd}^{3}$.

3. Allowing for volumetric expansion from the specific weight of compacted alluvium in place (U.S. Bureau of Reclamation, 1960) to that of newly deposited sediment, the volume of sediment is

$$
\frac{114 \mathrm{lb} / \mathrm{ft}^{3}}{70 \mathrm{lb} / \mathrm{ft}^{3}} \times 900 \mathrm{yd}^{3}=1,466 \mathrm{yd}^{3} .
$$




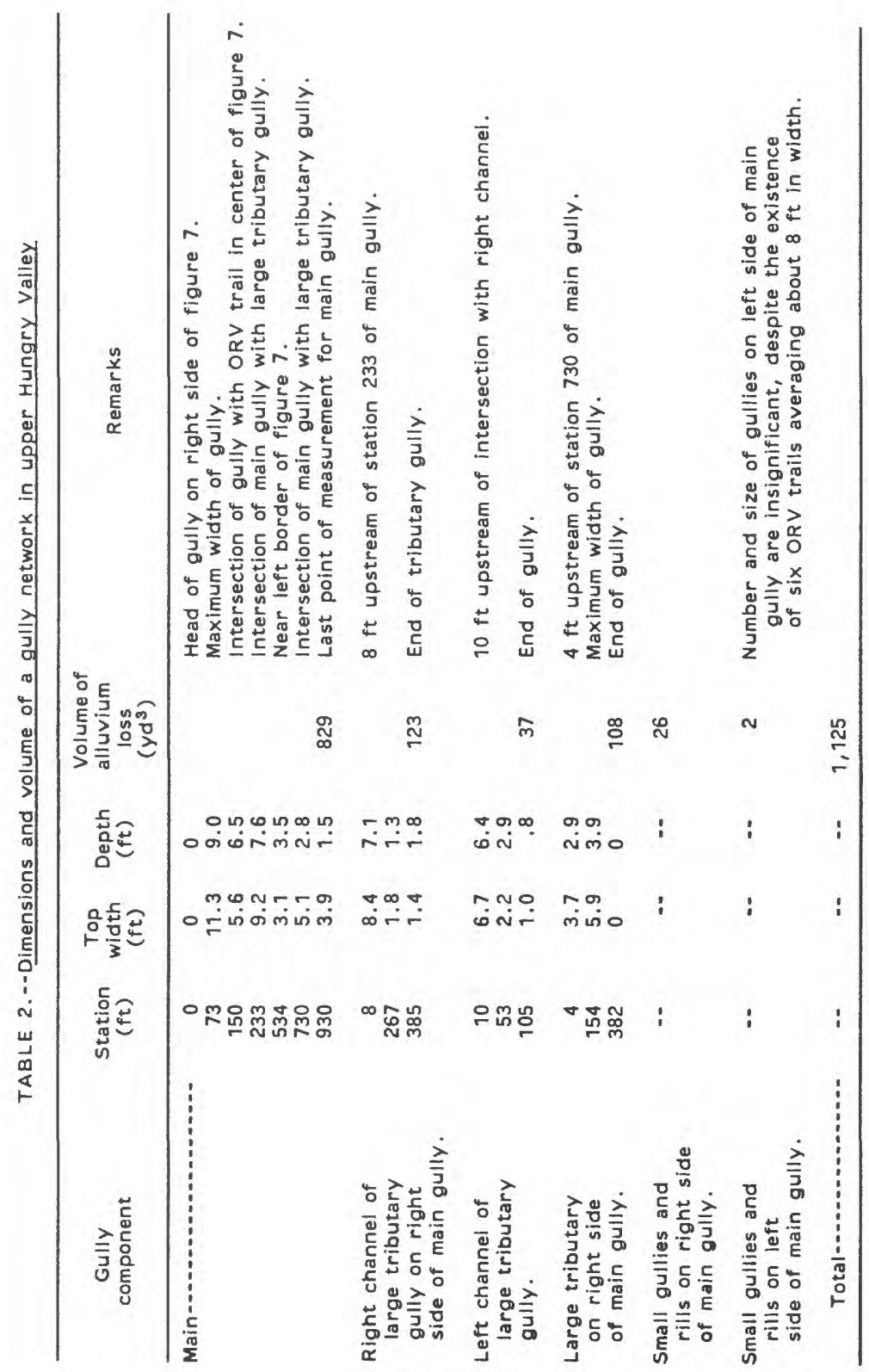


4. The eroded sediment throughout the upper Hungry Valley subbasin (4.67 $\mathrm{mi}^{2}$ and 20-percent impacted area) is

$$
\frac{1,466 \mathrm{yd}^{3}}{0.02 \mathrm{mi}^{2}} \times 4.67 \mathrm{mi}^{2} \times 0.20=68,500 \mathrm{yd}^{3}
$$

and that eroded in the lower Hungry Valley subbasin (9.35 $\mathrm{mi}^{2}$ and 1-percent impacted area) is

$$
\frac{1,466 \mathrm{yd}^{3}}{0.02 \mathrm{mi}^{2}} \times 9.35 \mathrm{mi}^{2} \times 0.01=6,850 \mathrm{yd}^{3}
$$

The volume of additional sediment accountable to ORV use in the upper and lower Hungry Valley subbasins is about $75,000 \mathrm{yd}^{3}$. A large part of this eroded sediment will not be transported out of the basin, because as the basin size increases the stream gradients decrease and the opportunity for intrabasin deposition increases (Scott and others, 1968). A sediment-delivery ratio curve by Renfro (1975) indicates that an average $14-\mathrm{mi}^{2}$ drainage area would have a delivery ratio of 16 percent. However, because ORV use results in the compaction of soil over a large part of the impact area, the runoff is significantly increased (Snyder and others, 1976). The author suggests that the normal major-storm sediment yield of the Cañada de los Alamos basin should be increased by $25,000 \mathrm{yd}^{3}$ to allow for the present level of ORV use.

\section{Long-Term Sediment Yields}

Long-term sediment yields for small basins (5-10 $\mathrm{mi}^{2}$ ) in the Transverse Ranges range from 10 to 13 percent of major-storm sediment yields (Scott and Williams, 1978). If the larger value is applied to the Cañada de los Alamos basin $\left(31 \mathrm{mi}^{2}\right)$, the long-term sediment yield is about $13,000 \mathrm{yd}^{3} / \mathrm{yr}$ or $420\left(\mathrm{yd}^{3} /\right.$ $\left.\mathrm{mi}^{2}\right) / \mathrm{yr}$. Scott and others (1968) estimated that the long-term sediment yield for the Piru Creek basin 
above Pyramid Lake $\left(284 \mathrm{mi}^{2}\right)$ was 1,270 $\left(\mathrm{yd}^{3} /\right.$ $\left.\mathrm{mi}^{2}\right) / \mathrm{yr}$. The low sediment yield of Cañada de los Alamos, relative to that for the total catchment area above Pyramid Lake, is considered reasonable because the basin typically receives less rainfall, has a more gentle topography, and has been less affected by wildfires.

\section{ORV IMPACTS ON THE ENVIRONMENT}

In recent years the use of ORV's on Federal, State, and local lands has increased greatly. According to a report by the Committee on Environment and Public Policy (1977), the number of ORV's in the United States increased from 5 million in 1972 to more than 12 million in 1977. The increased number of vehicles has resulted in intensified use in many places and a search for additional areas for ORV use. Short-term impacts of these vehicles on the environment have been documented by many studies, most of which have been made in California. Some of the major impacts of ORV use in California (excluding snowmobiles) are summarized and discussed in the following sections:

1. Erosion. Erosion rates of soil and subsoil are usually accelerated by ORV's. The ORV mechanically displaces or loosens surface soil particles by abrasion. During periods of insignificant rainfall, these soil particles are commonly moved downhill by gravity or transported by the wind. Trenching on motorcycle hillclimb trails commonly ranges from a few tenths to $1 \mathrm{ft}$, but trenching of $6 \mathrm{ft}$ in soft rocks and $2 \mathrm{ft}$ in hard rocks has been reported (Committee on Environment and Public Policy, 1977). During periods of significant rainfall, areas of loose soil on moderate to steep slopes are susceptible to accelerated erosion, and extensive gully networks may be created. Wilshire and others (1978) reported that measured soil losses from vehicle-use zones at seven sites in the San Francisco Bay area ranged from 7 to $1,180 \mathrm{~kg} / \mathrm{m}^{2}$ ( 1.4 to $\left.240 \mathrm{lbs} / \mathrm{ft}^{2}\right)$.

2. Sediment transport and deposition. The quantity of sediment transported from ORV sites will gen- 
erally be larger than that transported under original conditions. The quantity of sediment transported is affected by the size of particles, streamflow characteristics, and the existence of downstream structures, such as dams. Snyder and others (1976) reported that sediment yield from the Panoche Hills ORV site in central California was $857 \mathrm{~m}^{3} / \mathrm{km}^{2}(2,900$ $\left.\mathrm{yd}^{3} / \mathrm{mi}^{2}\right)$, compared to an insignificant sediment yield from the unused area.

3. Soil characteristics. ORV use generally compacts the subsurface soil, thereby increasing bulk density, reducing soil moisture, increasing soil temperature, and reducing infiltration. The above factors reduce the moisture available for plant growth and increase the amount of surface water runoff. Snyder and others (1976) and Wilshire and others (1978) reported soil compaction to a depth of more

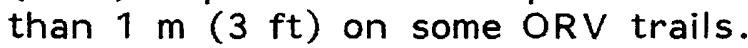

4. Vegetation. ORV's generally remove or destroy vegetal cover during contact and indirectly retard revegetation as discussed in item 3 . Snyder and others (1976) reported that following discontinuance of ORV use the vegetative cover on ORV trails increased from 20 percent in 1971 to 39 percent in 1975.

5. Runoff. Compaction of the soil and areas of bare soil result in a significant increase in surface water runoff. This increased runoff is often responsible for enlarged gullies and increased stream channel erosion. Snyder and others (1976) reported that runoff for the basin used by ORV's was eight times larger than that for the unused basin at the Panoche Hills site.

6. Esthetics. ORV's typically alter the appearance of the original landscape by removing vegetation and cutting trenches in hillsides. ORV trails are generally established as straight-line, circular, or crisscross patterns that may create a visual contrast between natural and manmade features. The esthetic impact of sites used for ORV recreation is largely dependent on individual judgment and opinion, but it is also influenced by the scenic quality of the original landscape and the extent and intensity of ORV use. 


\section{ORV IMPACTS IN HUNGRY VALLEY}

ORV activity in Hungry Valley has been intensive since 1971 (Wilshire, 1977). Although no hydrologic data are available for the valley, many of the ORV impacts described in studies of other areas apply to Hungry Valley. Sequential photographs representing a visual history of a severely impacted ORV site are shown in figures 8-13. These data were obtained as part of a nationwide study of vehicle impacts on natural terrain (H. G. Wilshire, U.S. Geological Survey, oral commun., 1978). According to measurements at three bench marks on the top of the hill, erosion losses averaged 8.2 inches from 1969 to January 1976 and 6.8 inches from January to September 1976. One of the bench marks was destroyed by erosion prior to September 1976 and the other two were destroyed between September 1976 and April 1977.

The most serious impacts of ORV's on the environment of Hungry Valley include significant loss of soil and alluvium from hillsides and formation of large gullies during major storms. Without basin management, these impacts could lead to the reduction of recreation and alternative land uses in upper Hungry Valley.

The impact on lower Hungry Valley could also be significant over the long term due to increased runoff. The alluvium in lower Hungry Valley is susceptible to extreme channel erosion during periods of high runoff. Floodflows during the February and March 1978 storms resulted in local downcutting and migration of stream channels. At a site on Cañada de los Alamos near Kinsey Ranch, the stream channel migrated laterally and removed $25 \mathrm{ft}$ of sediment from the left bank (fig. 14). At another site on a tributary to Cañada de los Alamos (fig. 15), the channel was changed from a shallow swale to a deeply incised channel, according to conversations with several persons working in the area. An evaluation of the effects of increased runoff on the lower reaches of Cañada de los Alamos is beyond the scope of this study, but these effects should be considered in the planning of basin-management measures. 


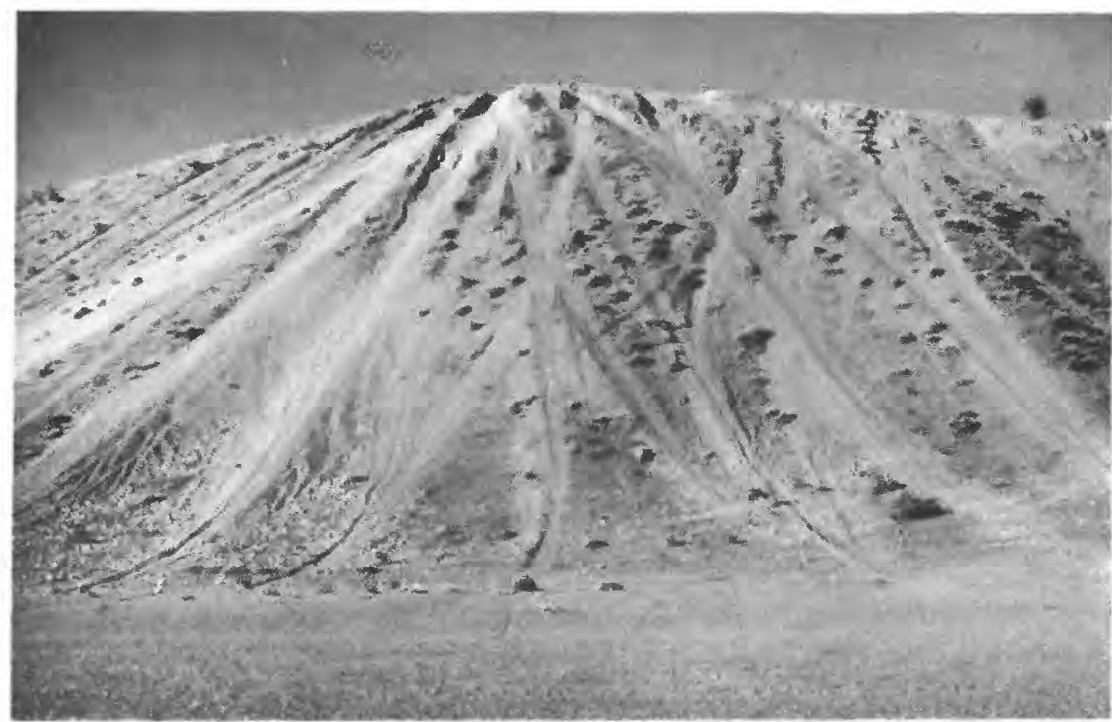

FIGURE 8.--"Bench Mark Hill" in January 1976 (vertical distance from base to crest about $130 \mathrm{ft}$ ). Erosion is largely due to surface abrasion by ORV's. Photograph by Howard Wilshire, Geologic Division, U.S. Geological Survey.

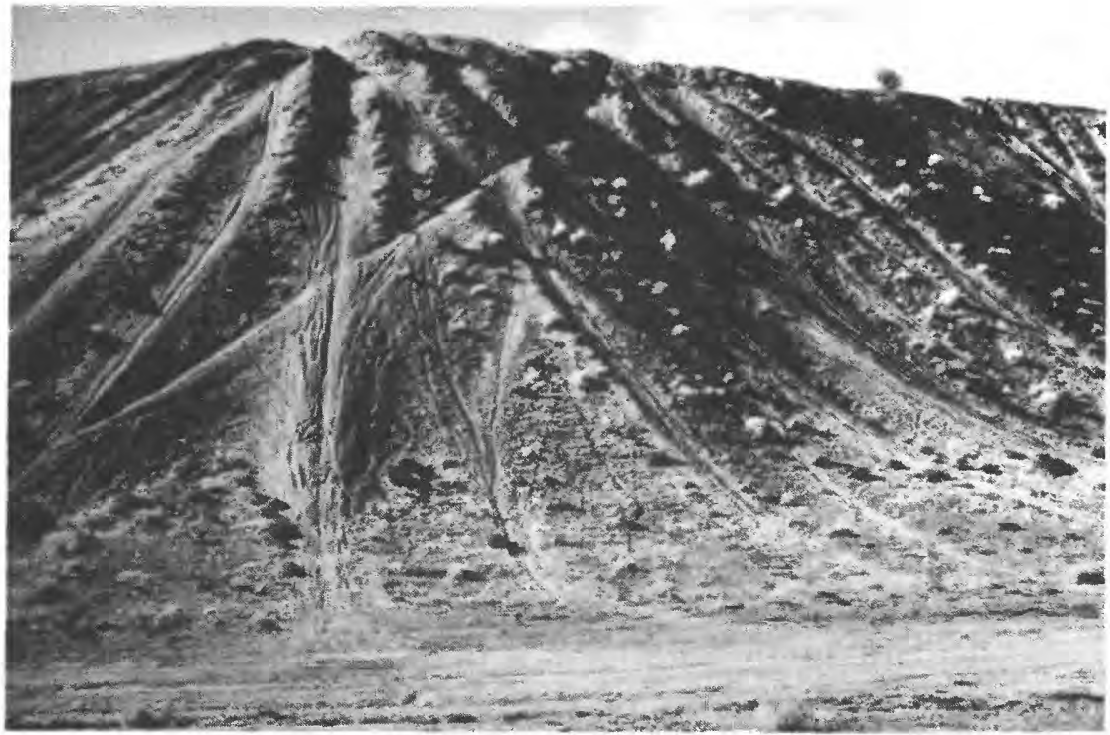

FIGURE 9.--"Bench Mark Hill" in January 1978. Photograph by Howard Wilshire, Geologic Division, U.S. Geological Survey. 


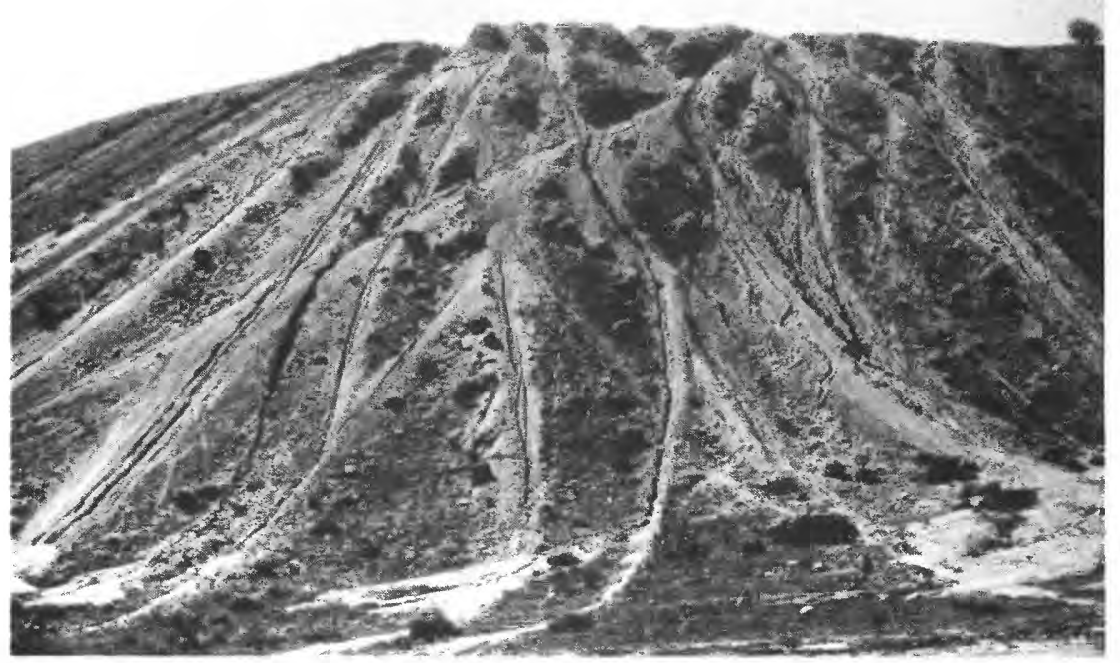

FIGURE 10.--"Bench Mark Hill" in March 1978. Many rills and small gullies formed during intense rainstorms in February and March. Small sediment deposits are evident at the mouths of gullies. Photograph by Howard Wilshire, Geologic Division, U.S. Geological Survey.

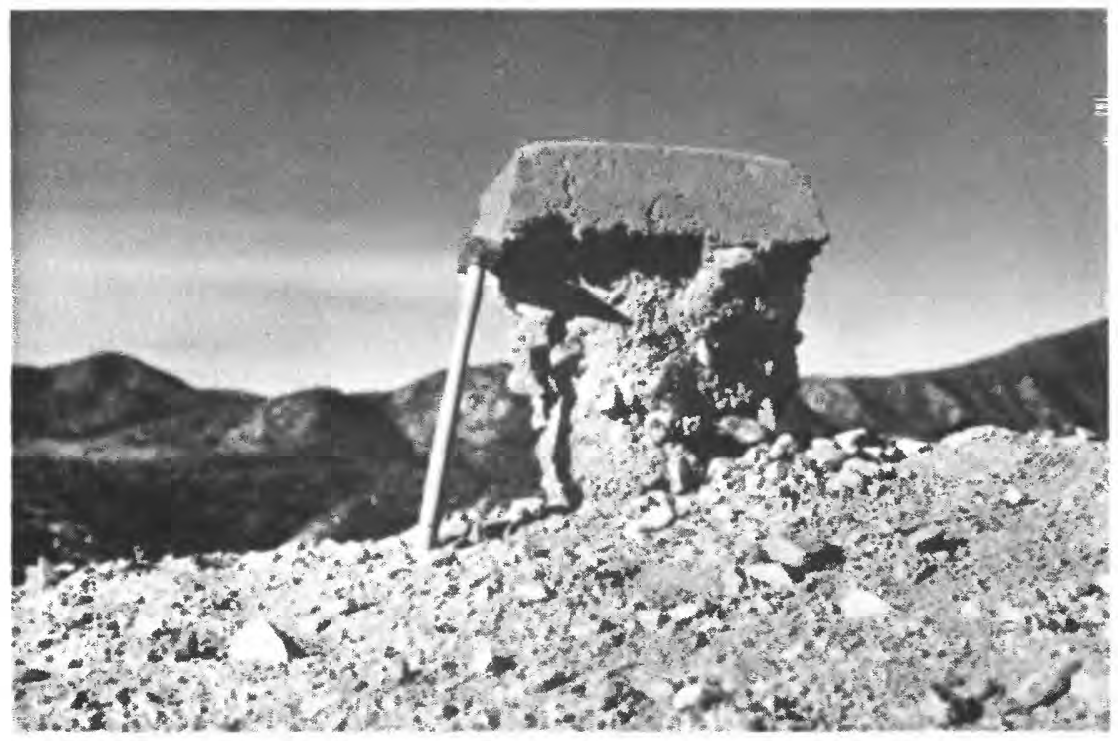

FIGURE 11.--Severely eroded benchmark on "Bench Mark Hill" in January 1976. This benchmark had been eroded out and, by April 1977, had rolled down the hill. Photograph by Howard Wilshire, Geologic Division, U.S. Geological Survey. 


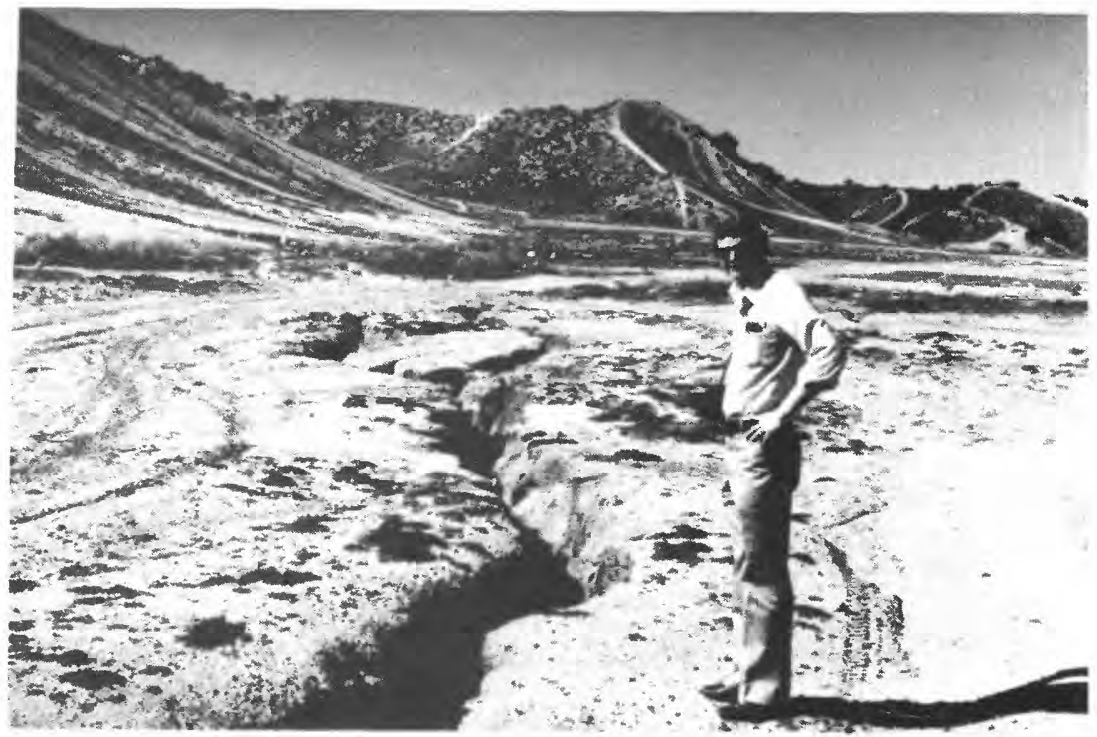

FIGURE 12.--One of numerous gullies formed at the base of "Bench Mark Hill" during the February and March 1978 rainstorms.

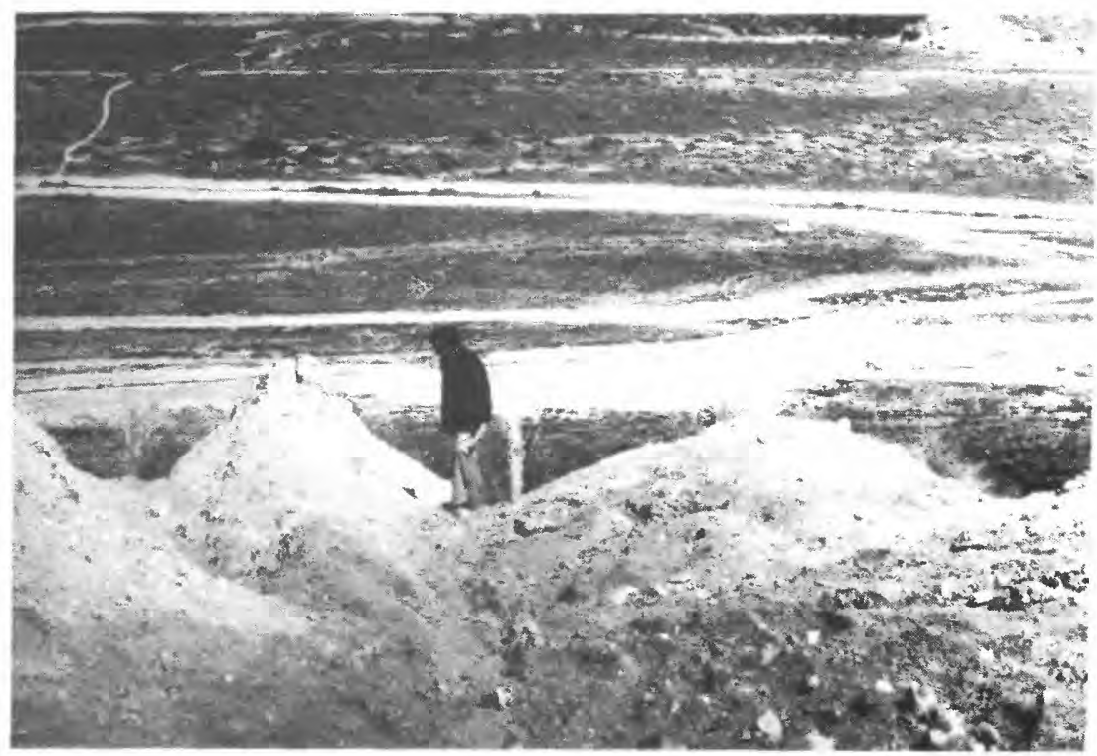

FIGURE 13.--Trenches eroded by surface abrasion of ORV's on top of "Bench Mark Hill." 


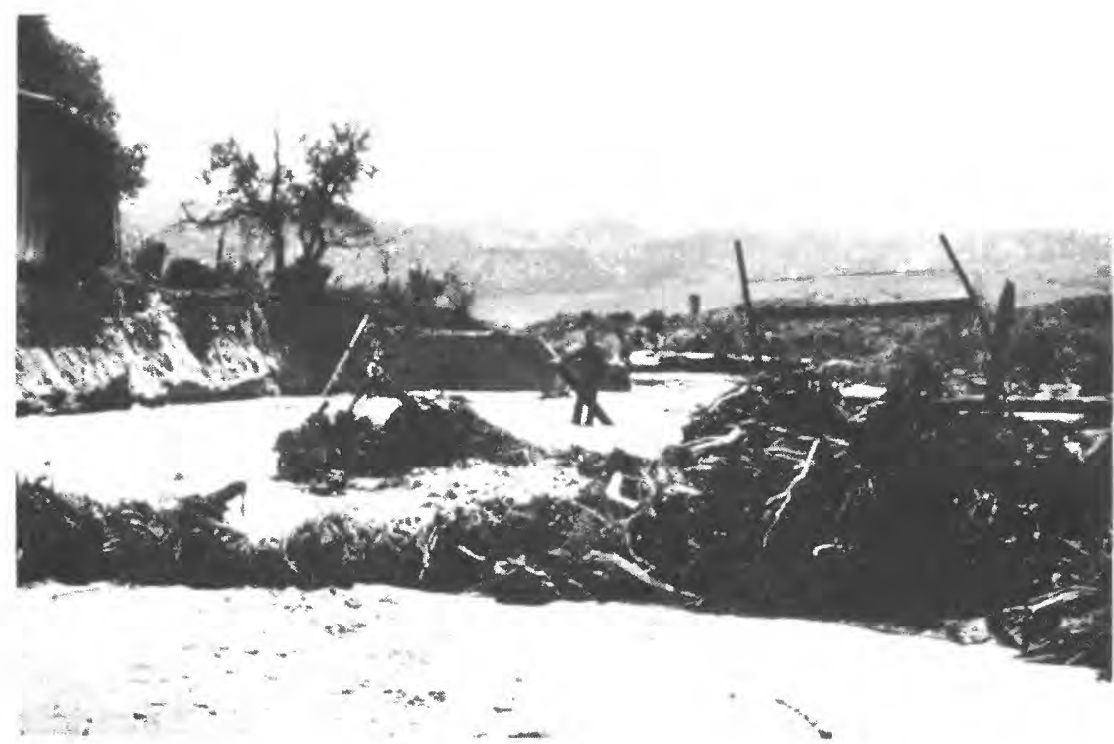

FIGURE 14.--Lateral migration of Cañada de los Alamos near Kinsey Ranch during February and March 1978. Channel receded $25 \mathrm{ft}$ on left bank exposing pipeline to pumphouse. Original soil deposited on pipe indicates a maximum stream depth of about $3 \mathrm{ft}$ near pipeline.

\section{BASIN MANAGEMENT}

Some of the more serious impacts of ORV use on the environment of Hungry Valley could be reduced or avoided by a coordinated program of basin management to insure that:

1. Hillclimbs are located away from established stream channels, and slope lengths are reduced on steep hillsides.

2. Hillclimbs are located on south- and westfacing slopes, where vegetation is sparse and soilmoisture retention is low, thus reducing the impact on wildlife habitat and esthetics.

3. Alternatives are provided, such as challenging obstacle courses constructed on gentle slopes of the valley floor. 
4. Cross-country trails follow natural contours and avoid landslide- or slump-prone areas.

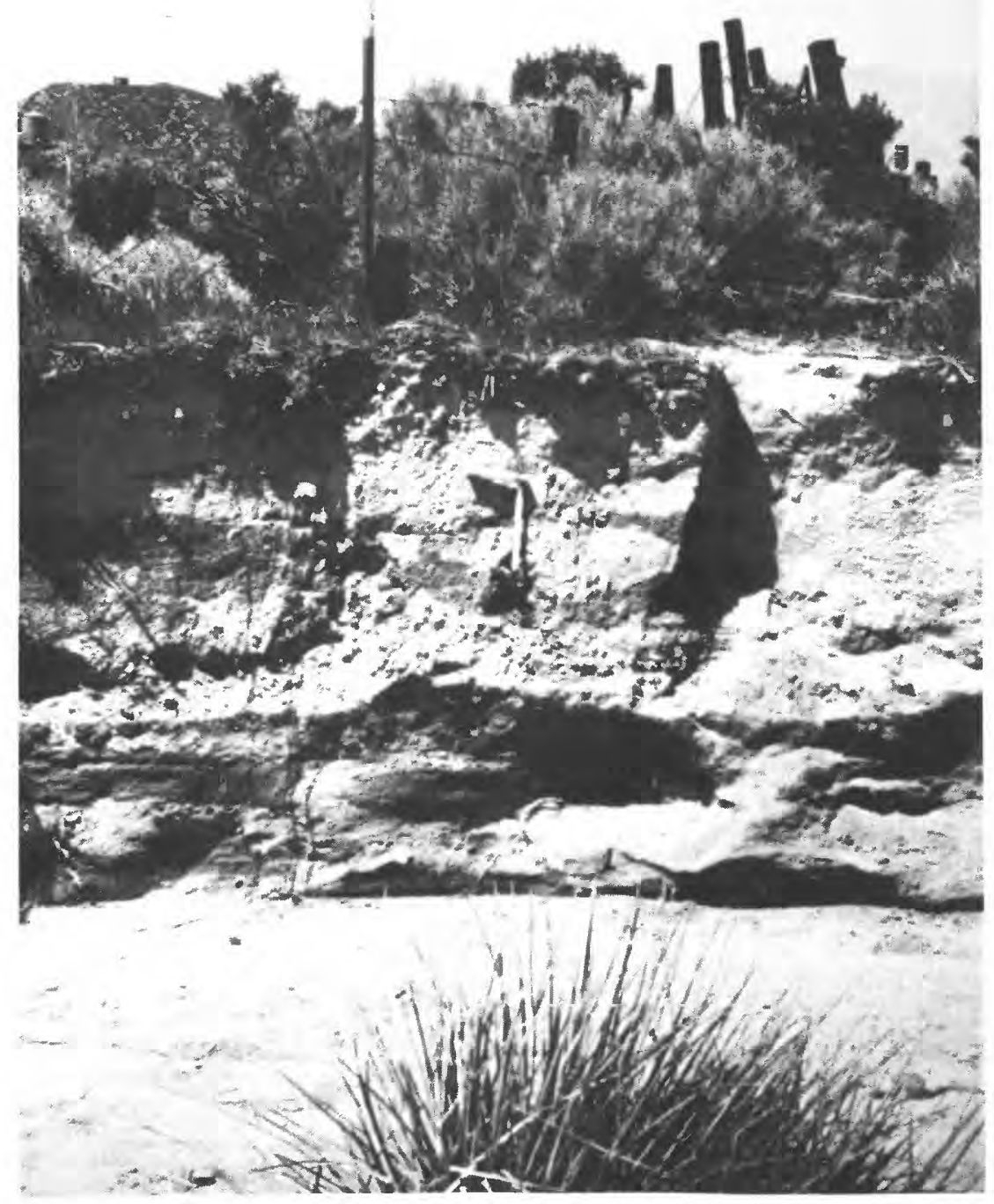

FIGURE 15.--Downcutting of a tributary to Cañada de los Alamos near Kinsey Ranch. Channel was a shallow swale prior to March 1978. The channel was about $5 \mathrm{ft}$ deep and $30 \mathrm{ft}$ wide in April 1978. 
5. Puncheons, turnpikes, culverts, bridges, and other trail stabilization devices (Rasor, 1976) are used to reduce erosion and control runoff.

6. Roads from camping and sanitary facilities to recreation sites are properly planned and maintained to prevent erosion and destruction of vegetal cover outside of recreation sites.

7. ORV areas that are closed to recreation use are rehabilitated by treatment of gullies and rills, replacement of topsoil, and revegetation.

8. Debris basins, windbreaks, and gully-control structures are used to reduce or delay sediment transport from ORV sites.

9. Debris basins, revegetation, and diversion of flow to spreading areas are used to reduce storm runoff.

\section{IMPACT MONITORING}

An adequate monitoring program could be established to determine areas of unacceptably severe erosion, effectiveness of erosion control structures, and impacts on downstream reaches of Cañada de los Alamos. Monitoring techniques might include:

1. Periodic interpretation of aerial photographs.

2. Debris-basin surveys to determine area erosion rates.

3. Soil surveys to determine thickness and composition of remaining soil. Standards for permissible deterioration could be adopted in terms of a preplanned rehabilitation program.

4. Vegetation surveys to determine viability of native vegetation and intrusions of exotic species.

5. Stream-channel surveys to determine channel migration and changes in hydraulic geometry.

6. Climatological data collection.

7. Water and air quality surveys.

\section{SUMMARY AND CONCLUSIONS}

Unregulated ORV activities have resulted in adverse impacts in the upper part of Hungry Valley. These adverse impacts include accelerated erosion, 
increased runoff, increased sediment transport, loss of vegetation, soil compaction, and esthetic degradation. The cumulative impact is largest in areas of intensive ORV. use. Downstream impacts, such as stream-channel migration and erosion, may be significant over the long term.

Long-term sediment yield of the Cañada de los Alamos basin under present conditions is estimated to be $420\left(\mathrm{yd}^{3} / \mathrm{mi}^{2}\right) / \mathrm{yr}--\mathrm{a}$ rate that is considerably lower than a previous estimate of $1,270\left(\mathrm{yd}^{3} / \mathrm{mi}^{2}\right) / \mathrm{yr}$ for the total catchment area above Pyramid Lake. The large variance in sediment yields for the two areas is primarily attributed to significant differences in rainfall, topography, and fire history.

Most of the more serious impacts of ORV use on the environment of Hungry Valley could be reduced by a coordinated program of planning, regulation, maintenance, and corrective treatment. Long-term erosion control can be effected by an adequate program of rehabilitation based on recognized watershed-management principles. A monitoring program would allow an assessment of the effectiveness of erosion control structures and impacts on downstream channels.

\section{SELECTED REFERENCES}

Committee on Environment and Public Policy, 1977, Impacts and management of off-road vehicles: Geological Society of America, 8 p.

Crowell, J. C., 1950, Geology of Hungry Valley area: American Association of Petroleum Geology, v. 34, no. 8, p. 16231646.

Jennings, C. W., and Strand, R. G., 1969, Los Angeles sheet of geologic map of California: California Division of Mines and Geology Map Sheet.

National Climatic Center, 1969, Climatological data--California: Asheville, N.C., National Oceanic and Atmospheric Administration, v. 73 , no. $1,35 \mathrm{p}$.

1978, Climatological data--California: Asheville, N.C., National Oceanic and Atmospheric Administration, $v .82$, no. 2 , 35 p.; v. 82, no. 3, 35 p.

Rantz, S. E., 1969, Mean annual precipitation in the California Region: U.S. Geological Survey open-file map.

Rasor, Rob, 1976, Fair Share: American Motorcycle Association, P. 16-17. 
Renfro, G. W., 1975, Use of erosion equations and sedimentdelivery ratios for predicting sediment yield: U.S. Department of Agriculture, ARS-S-40, P. 38.

Scott, K. M., Ritter, J. R., and Knott, J. M., 1968, Sedimentation in the Piru Creek watershed, southern California:

U.S. Geological Survey Water-Supply Paper 1798-E, 48 p.

Scott, K. M., and Williams, R. P., 1978, Erosion and sediment yields in the Transverse Ranges, southern California: U.S. Geological Survey Professional Paper 1030, $38 \mathrm{p}$.

Snyder, C. T., Frickel, D. G., Hadley, R. F., and Miller, R. F., 1976, Effects of off-road vehicle use on the hydrology and landscape of arid environments in central and southern California: Denver, Colo., U.S. Geological Survey WaterResources Investigations 76-99, $45 \mathrm{p}$.

U.S. Bureau of Reclamation, 1960, Design of small dams: Washington, D.C., P. 95-98.

Webb, R. H., and Wilshire, H. G., 1978, A bibliography of the effects of off-road vehicles on the environment: U.S. Geological Survey Open-File Report 78-149, 15 p.

Wilshire, H. G., 1977, Study results of nine sites used by offroad vehicles that illustrate land modifications: U.S. Geological Survey Open-File Report 77-601, $19 \mathrm{p}$.

Wilshire, H. G., and Nakata, J. K., 1978, Erosion of off-road vehicle sites in southern California, in Berry, K. (ed.), Proceedings of the Symposium on the physical, biological, and recreational impacts of off-road vehicles on the California desert: Southern California Academy of Sciences, Special Publications, in press.

Wilshire, H. G., Nakata, J. K., Shipley, Susan, and Prestegaard, Karen, 1978, Impact of vehicles on natural terrain at seven sites in the San Francisco Bay area: Environmental Geology, v. 2, no. 4 , p. 1-25. 